\title{
Neutrophil extracellular traps contribute to the pathogenesis of acid-aspiration-induced ALI/ARDS
}

\author{
Haitao Li ${ }^{1}$, Xiaoting Zhou ${ }^{2}$, Hongyi Tan $^{3}$, Yongbin $\mathrm{Hu}^{4}$, Lemeng Zhang ${ }^{5}$, Shuai Liu ${ }^{1}$, \\ Minhui Dai ${ }^{1}$, Yi Li ${ }^{1}$, Qian Li ${ }^{1}$, Zhi Mao' ${ }^{1}$, Pinhua Pan ${ }^{1}$, Xiaoli Su${ }^{1}$ and Chengpin $\mathrm{Hu}^{1}$ \\ ${ }^{1}$ Department of Pulmonary and Critical Care Medicine, Key Site of National Clinical Research Centre for Respiratory Disease, \\ Xiangya Hospital, Central South University, Changsha 410008, China \\ ${ }^{2}$ Department of Neurology, Xiangya Hospital, Central South University, Changsha 410008, China \\ ${ }^{3}$ Department of Respiratory Medicine, Changsha Central Hospital, Changsha, 410004, China \\ ${ }^{4}$ Department of Pathological Medicine, Xiangya Hospital, Central South University, Changsha 410008, China \\ ${ }^{5}$ Department of Thoracic Medicine, Hunan Cancer Hospital, Affiliated to Xiangya Medical School, Central South University, \\ Changsha, 410013, China
}

Correspondence to: Pinhua Pan, email: pinhuapan668@126.com

Keywords: neutrophil extracellular traps(NETs); acid-aspiration; acute lung injury(ALI); acute respiratory distress syndrome(ARDS)

Received: July 28, $2017 \quad$ Accepted: October 30, $2017 \quad$ Published: November 28, 2017

Copyright: Li et al. This is an open-access article distributed under the terms of the Creative Commons Attribution License 3.0 (CC BY 3.0 ), which permits unrestricted use, distribution, and reproduction in any medium, provided the original author and source are credited.

\section{ABSTRACT}

Background: Acute lung injury/acute respiratory distress syndrome (ALI/ARDS) is a manifestation of systemic inflammation in the lungs, but the factors that trigger inflammation in ALI/ARDS are unclear. We hypothesized that neutrophil extracellular traps (NETs) contribute to the pathogenesis of acid aspiration-induced ALI/ARDS.

Results: Analysis of bronchial aspirates from ARDS patients showed that NETs were significantly correlated with the degree of ARDS $(r=-0.5846, p=0.0359)$. NETs in bronchoalveolar lavage fluid of acid-aspiration mice were significantly higher $(141.6 \pm 23.08)$ at $3 \mathrm{~h}$ after injury than those in the sham group (1234 \pm 101.9 ; $p=0.003, n=5$ per group). Exogenous NETs aggravated lung injury, while alvelestat and DNase markedly attenuated the intensity of ARDS.

Materials and Methods: We investigated whether NETs are involved in the severity of gastric aspiration-induced ARDS. Then, a hydrochloric acid aspiration-induced ALI murine model was used to assess whether NETs are pathogenic and whether targeting NETs is protective. Exogenous NETs were administered to mice. Alvelestat can inhibit neutrophil elastase (NE), which serves an important role in NET formation, so we investigated whether alvelestat could protect against ALI in cell and mouse models.

Conclusions: NETs may contribute to ALI/ARDS by promoting tissue damage and systemic inflammation. Targeting NETs by alvelestat may be a potential therapeutic strategy.

\section{INTRODUCTION}

Acute lung injury/acute respiratory distress syndrome (ALI/ARDS) is caused by inflammatory lung injury that results in severe, diffuse increased alveolarcapillary permeability. Consequently, edema, hypoxia, and hemorrhage follow. Effective advanced care measures, such as lung-protective ventilation and fluid-conservation management, have been applied in clinical practice for years, but ARDS is still a major risk to patients in intensive care units, with hospital mortality rates of $40 \%$ or more $[1,2]$.
Pneumonia, aspiration and sepsis are the leading causes of ARDS; these conditions lead to tissue injury and inappropriate accumulation of inflammatory factors, along with leukocyte activation. These changes eventually activate inflammatory cascades, which lead to alveolar barrier disruption, resulting in severe conditions such as respiratory failure $[1,3]$. Common pathological features of ARDs include rapid recruitment of leukocytes and release of proinflammatory cytokines, triggering systemic inflammation $[1,4]$. However, how these factors "pull the trigger" in ARDS is still unclear. 
Identification of core factors that mediate inflammation in ARDS is critical.

Neutrophil extracellular traps (NETs) are networks of extracellular fibers, primarily composed of DNA, which are embedded with histones, myeloperoxidase (MPO) and neutrophil elastase (NE) and released from neutrophils to bind pathogens [5]. Recently, NETs have been shown to be potential mediators in noninfectious systemic inflammatory diseases, including sepsis, acute ischemiareperfusion injuries of the liver, and transfusion-related or LPS-induced acute lung injury [6-9]. These findings indicate that NETs have many functions, including induction of alveolar-capillary barrier damage, platelet aggregation, and cytokine production, all of which are likely involved in the pathogenesis of ALI/ARDS.

Aspiration was identified a major cause of ALI/ ARDS in previous studies [10-13], and acid aspiration is known as a neutrophil-dependent form of ALI/ARDS characterized by injury of both the alveolar epithelium and the capillary endothelium $[14,15]$. Therefore, we hypothesized that NETs in aspiration play a significant role in the progression of ARDS. Furthermore, inhibition of NET production or degradation of NETs may be potential therapeutic approaches in acid-aspiration-induced ALI/ ARDS.

To verify this hypothesis, we first enrolled 13 patients with ARDS caused by aspiration of gastric contents to analyze the correlation between the clinical severity and the level of NETs. Then, we established an acid aspiration murine model of acute lung injury, which simulates acute gastric aspiration injury in the clinic $[3,16]$, to investigate whether NETs released after lung injury have pathogenic roles. In addition, we assessed whether inhibitors of NET production have beneficial effects in the acute lung injury model to identify new strategies for treatment of ARDS. A previous study showed that NE played a central role in the formation of NETs, and NE is one component of NETs [17-19]. Alvelestat (AZD9668), an NE inhibitor, can prevent human NE-induced lung injury in mice and rats and reduce the inflammatory response [20]. Therefore, we sought to explore whether alvelestat has the potential to attenuate acid aspiration-induced lung injury through degradation and inhibition of NETs.

\section{RESULTS}

\section{NETs indicate disease severity in gastric aspiration-induced ARDS patients}

Thirteen ARDS patients (8 men and 5 women with a mean age of $54 \pm 6.3$ years) with a recent gastric aspiration history were enrolled in the study. All patients had a history of gastric aspiration events within one week, with associated aspiration signs, such shortness of breath and appearance of a new infiltrative shadow on a chest X-ray. We characterized NETs (Figure 1D) in bronchial aspirates by co-localization of citrullinatedhistone3 (cit-H3) (Figure 1A) and NE (Figure 1B) using immunofluorescence analyses. Furthermore, we measured the NET-DNA levels in the supernatant of bronchial aspirates for quantitative analysis of these patients (Figure 1E). There was a significant correlation of NET-DNA in bronchial aspirate with arterial oxygen tension/inspired oxygen fraction $\left(\mathrm{PaO}_{2} / \mathrm{FiO}_{2}\right)(\mathrm{r}=-0.5846$, $p=0.0359$ ) in patients' blood gas analysis index, suggesting that NETs aggravated pulmonary ventilation dysfunction in ARDS. We concluded that NETs might reflect disease severity of ARDS in clinical situations.

\section{NETs are increased in mice with acid aspiration- induced lung injury}

Administration of $\mathrm{HCl}$ to mice resulted in significant lung damage, as reflected by the decreased $\mathrm{PaO}_{2}(83.4 \pm 1.965$ vs $64.2 \pm 5.342, n=5$ per group, $p=0.0194$; Figure 2A) and the increased lung wet/ dry weight ratio $(3.02 \pm 0.102$ vs $4.72 \pm 0.1881$ at $6 \mathrm{~h}$, $n=5$ per group, $p=0.0002$; Figure $2 \mathrm{~B}$ ), both of which are indicators of ARDS. Lung histological examination at $6 \mathrm{~h}$ (Figure 2F) after $\mathrm{HCl}$ challenge demonstrated multifocal alveolar hemorrhage, diffuse disruption of the alveolar wall, and massive inflammatory cell infiltration, while at $0 \mathrm{~h}$ (Figure 2E), there was minimal lung injury. Immunofluorescence microscopy of lung tissue at $6 \mathrm{~h}$ after $\mathrm{HCl}$ challenge also showed the presence of NETs, as determined by co-localization of cit-H3 and NE (Figure 2G). Similarly, the levels of NET-DNA were increased in the BALF of mice after the $\mathrm{HCl}$ challenge (Figure 2D). As a semi-quantitative analysis of NETs, the presence of cit-H3 in BALF detected by Western blotting (Figure 2C) was increased in a time-dependent manner, with similar results obtained from lung tissue immunofluorescence of NETs. The release of NET-DNA into the BALF occurred in a time-dependent manner, which correlated with the severity of ARDS.

\section{Exogenous NETs aggravate lung inflammation in mice with ARDS}

In further experiments, we assessed whether NETs released during ARDS contributed to inflammation and lung injury in this model. First, we showed that pulmonary instillation of mouse marrow-derived NETs at a DNA concentration of $1.5 \mathrm{mg} / \mathrm{kg}$ alone resulted in mild lung damage in mice, as shown by an increase in BALF LDH levels at $12 \mathrm{~h}$, compared to saline-treated mice $(61 \pm 8.258$ vs. $151.6 \pm 22.29, n=5$ per group, $p=0.0052$; Figure 3 A). Notably, administration of exogenous NETs immediately after $\mathrm{HCl}$ challenge significantly increased the death rate of mice compared with the $\mathrm{HCl}$ onlytreated group (Figure 3B, $p=0.0209$ ). Exogenous NETs 
aggravated acid-induced lung injury in mice, as shown by enhanced lung injury scores (HCl-treated group $6.6 \pm 0.6$ vs HCl-treated + exogenous NETs group $9 \pm 0.7071, n=5$ per group, $p=0.0322$; Figure $3 \mathrm{C}, 3 \mathrm{~J}$ ) and the increased inflammatory cytokines (TNF- $\alpha$, IL-1 $\beta$, IL-6) in BALF (Figure 3D-3F) and in plasma (Figure 3J-3I). Several of these cytokines are associated with the development and progression of ARDS in humans [21, 22]. Therefore, our data confirmed that NETs contribute to ARDS in mice after acid aspiration.

\section{Attenuation of NETs is protective in mice with lung injury}

In this study, we also examined whether alvelestat, a neutrophil elastase that inhibits NET formation, has protective potential. DNase I, a NET degradation agent that was shown to decrease NETs in vivo in our previous study [9], was administered separately as a positive control. The counts of the citrullinated histone-NE complex (immunofluorescence characterization of NETs) in random fields were substantially reduced in lung tissues of the alvelestat-treated group, similar to the DNase-treated group, as shown by confocal microscopy (Figure 4A). Similar results were observed for the cit-H3/tubulin ratio (Figure 4B, 4C) in lung tissue and the NET-DNA concentration (Figure 4D) in BALF as semi-quantitative or quantitative analyses of NETs, respectively. Furthermore, both alvelestat and DNase I reduced lung injury in acidtreated mice as demonstrated by improved lung histology along with NET attenuation (Figure 5A, 5B). BALF and serum levels of IL-1 $\beta$, IL-6, and TNF- $\alpha$ (Figure 5C-5J) were reduced following inhibition of NET production. Collectively, these findings confirmed that NETs play a role in the progression of ARDS, and targeting NETs by inhibition or degradation is protective.

\section{In vitro studies}

As NE is a major component of NETs, we further examined whether alvelestat-mediated protection was also dependent on inhibition of NE activity in NETs. To address this issue, we first stimulated adenocarcinoma human alveolar epithelial cells (A549) and human bronchial epithelial cells (HBE) with exogenous human-derived NETs and observed that administration of NETs enhanced cell death in A549 cells, while NETs barely caused mild damage in HBE cells as shown by PI staining and flow cytometry analysis (Figure 6A). However, NETs could induce an inflammatory response in both A549 cells and HBE cells (Figure 6B), confirming that NETs possess direct cytotoxic effects and induce inflammation. Co-incubation of exogenous NETs with alvelestat, anti-NE antibody and DNase I decreased cytotoxicity and inflammatory
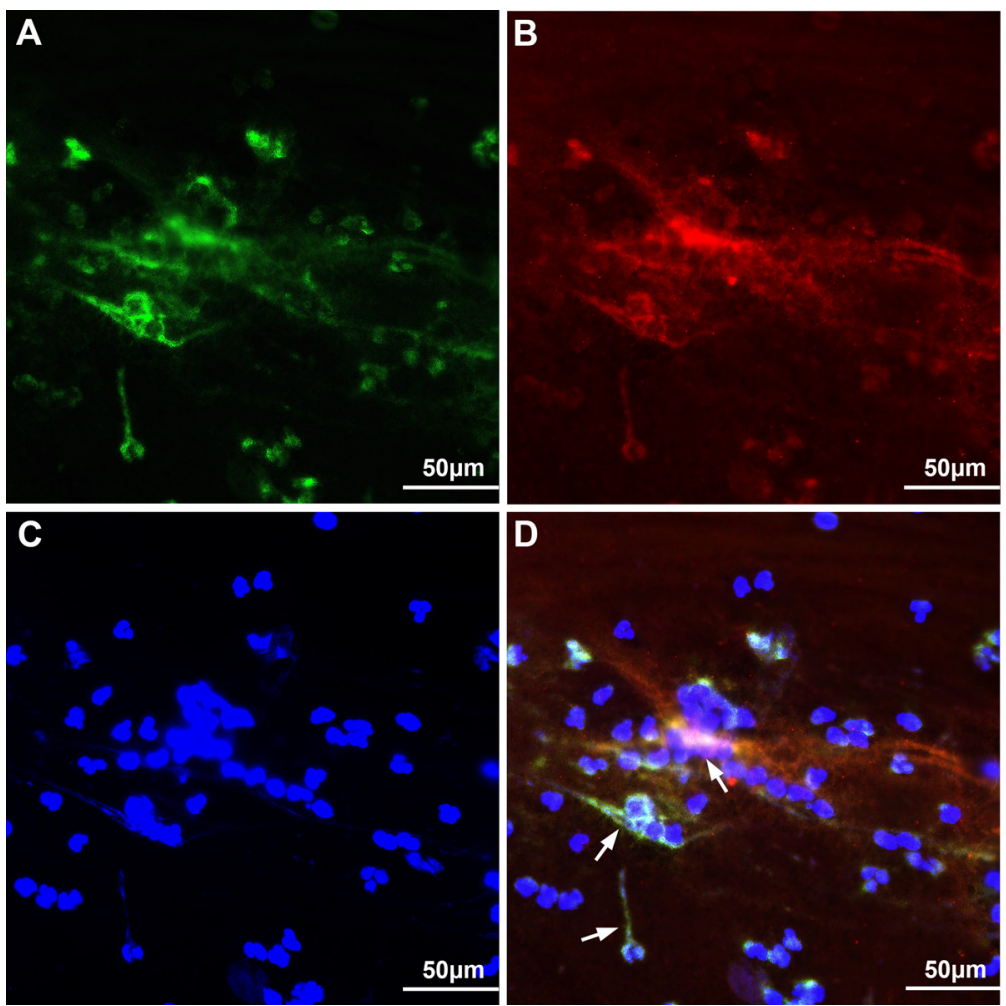

E

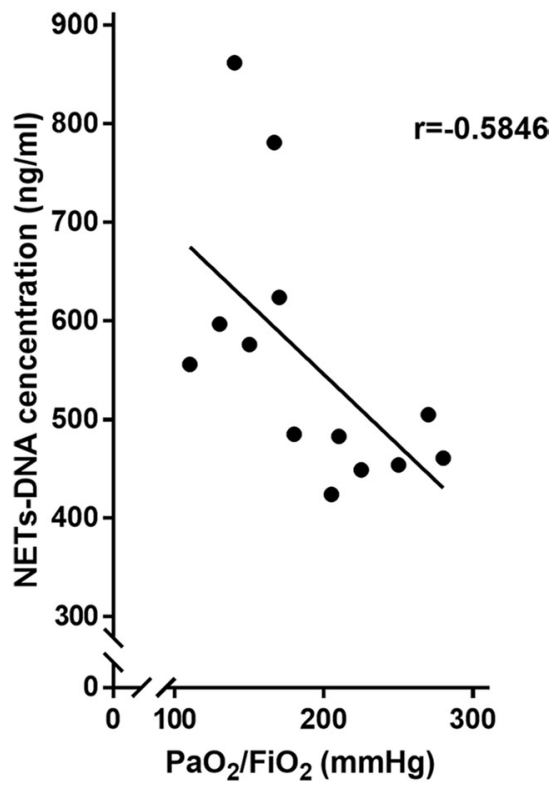

Figure 1: NETs were observed to determine the clinical relevance to disease severity in gastric aspiration-induced ARDS patients. NETs (white arrow in D) were characterized with cit-H3 (A), NE (B) and DNA (C) in bronchial aspirates from gastric aspiration-induced ARDS patients. (E) $\mathrm{PaO}_{2} / \mathrm{FiO}_{2}$ is highly correlated to NET concentration in bronchial aspirate from gastric aspirationinduced ARDS patients. 
responses, as demonstrated by the significantly alleviated cell death and reduced inflammatory cytokine levels in the supernatant of the culture medium. These results confirmed that cytoprotection and inflammatory responses are mediated by targeting NETs and their components, such as NE.

\section{DISCUSSION}

To date, ARDS is still the leading cause of respiratory failure in critically ill patients in the ICU and has high morbidity and mortality rates [1, 2].
Gastric aspiration is one of the leading causes of ARDS $[3,23,24]$. There is a broad range of conditions that predispose individuals to gastric aspiration-induced ARDS (e.g., general anesthesia and neurologic disorders), and $30-50 \%$ of gastric contents aspiration-induced ARDS patients eventually die of respiratory failure [3] despite receiving standard therapy. However, in contrast to sepsisassociated ARDS, the underlying mechanism of acid aspiration-induced ARDS is not well-known.

Accumulating evidence demonstrates that uncontrolled and persistent inflammatory responses are deeply implicated in the progress of ALI/ARDS, which
A

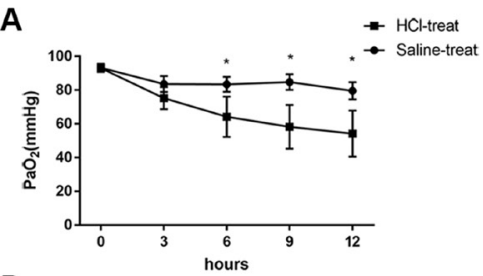

D

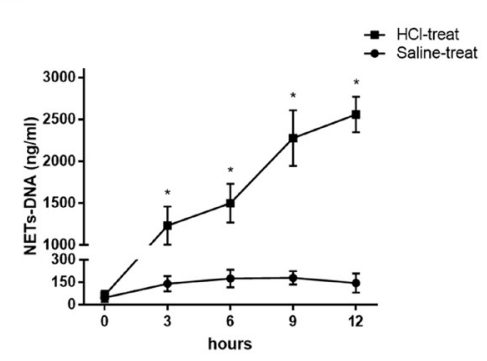

G
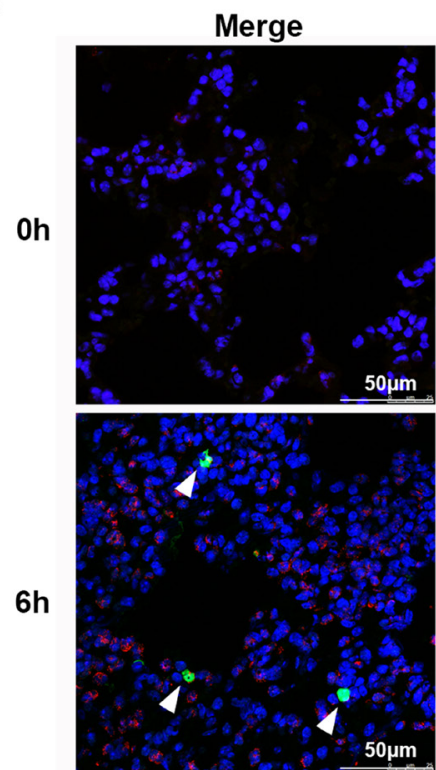

B

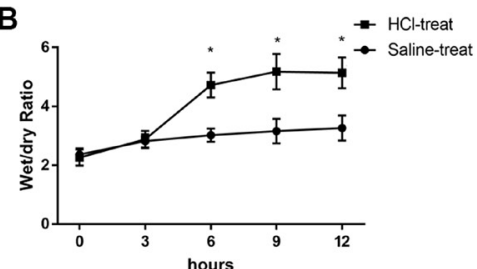

$\mathbf{E}$

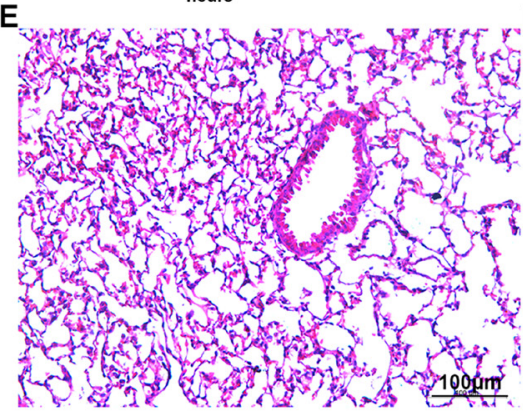

DAPI
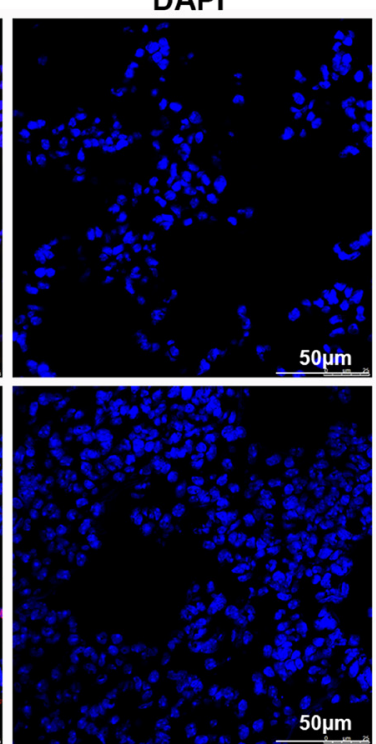
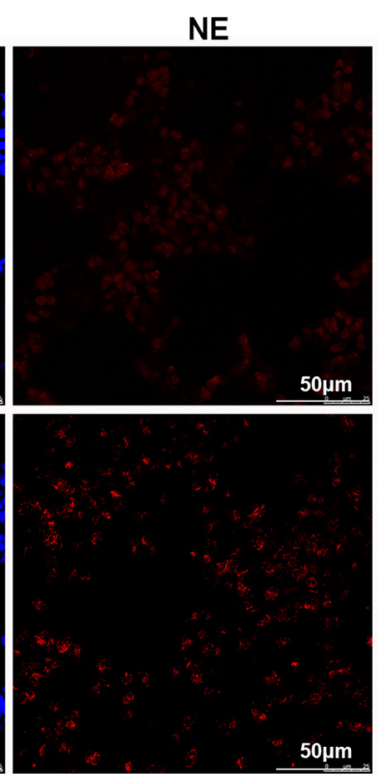

C

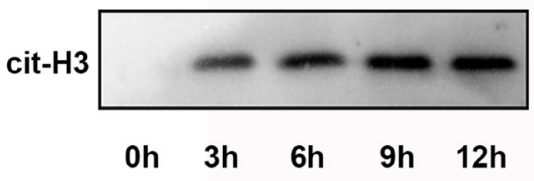

$F$

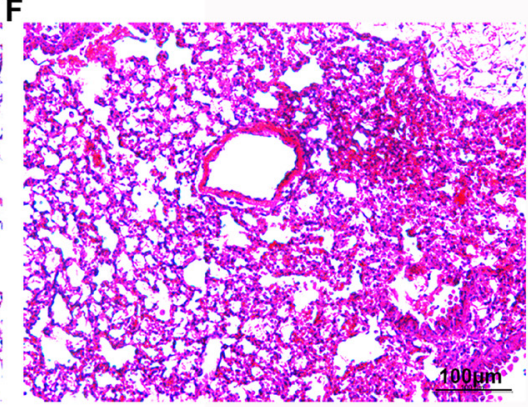

cit-H3
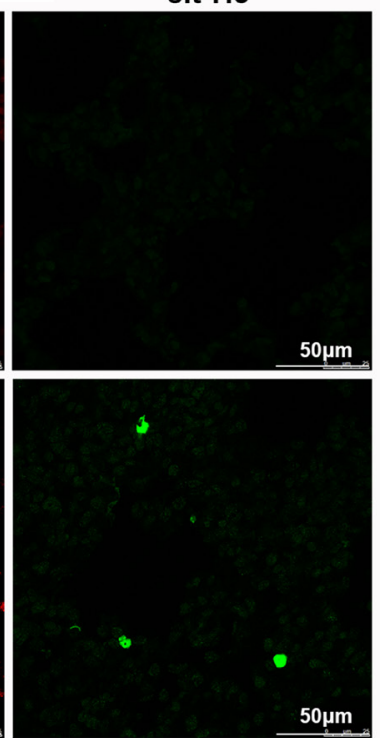

Figure 2: HCl aspiration caused ARDS as well as elevated NET levels in the BALF of mice. (A) $\mathrm{HCl}$ was used to challenge the mice and resulted in a decrease in $\mathrm{PaO}_{2}$ in a time-dependent manner ( ${ }^{*} p<0.05$ vs. the sham group). (B) Mouse lung wet-dry ratios were augmented after $\mathrm{HCl}$ aspiration $\left({ }^{*} p<0.05\right.$ vs the sham group). (C) An example of cit-H3 detected by Western blot in the BALF of mice after $\mathrm{HCl}$ aspiration. The blots are representative of at least three independent experiments. (D) $\mathrm{HCl}$ aspiration caused a significant increase in BALF NET-DNA of mice measured using PicoGreen ( ${ }^{*} p<0.05$ versus the sham group). Hematoxylin and eosin-stained sections of lung injury at $0 \mathrm{~h}(\mathbf{E})$ and $6 \mathrm{~h}(\mathbf{F})$ after $\mathrm{HCl}$ administration to mice. Obvious pathological changes were observed in the lungs of $\mathrm{HCl}$-treated mice, such as alveolar hemorrhage and infiltration of neutrophils. Scale bars: $100 \mu \mathrm{m}$. (G) Confocal microscopy of lung sections with immunofluorescence at $0 \mathrm{~h}$ and $6 \mathrm{~h}$ after $\mathrm{HCl}$ administration to mice. The complex of cit- $\mathrm{H} 3$ and $\mathrm{NE}$ (NETs) substantially increased at $6 \mathrm{~h}$, along with neutrophils. Scale bars: $50 \mu \mathrm{m}$. 
is characterized by massive leukocyte activation and cytokine release [21]. Moreover, damage-associated molecular pattern molecules (DAMPs), such as mitochondrial DNA, extracellular histones, high mobility group box-1 protein, and formyl peptides, have been shown to be a primary cause of uncontrolled inflammation in addition to pathogens [25-28]. During the process of NETosis, neutrophils (the most common type of infiltrating leukocytes) produce and release NETs, which are formed of extracellular deoxyribonucleic acid (eDNA) coated with histones, proteases and granular and cytosolic proteins, act as a danger-associated molecular patterns and are associated with inflammation and tissue injury [29]. As DAMPs, NETs also induce damage and inflammatory responses in several pathological scenarios in different organs by opposing the NETosis of neutrophils [30]. The aim of this study was to not only explore the relationship between the NET level and the disease severity of aspiration-induced ALI/ARDS but also to test the efficacy of attenuation of NETs as a treatment for ALI/ARDS in an experimental model of acid-induced lung injury.
Here, we found that the levels of NETs correlated with the disease severity of ALI/ARDS. Thus, we concluded that NETs may serve as a marker for clinically monitoring the severity of lung injury in humans. Then, we prepared a murine model of $\mathrm{HCl}$ aspiration-induced ARDS to study whether NETs are clinically relevant in aspiration of gastric acid and are associated with high mortality rates of ARDS [16, 21, 22]. $\mathrm{HCl}$ exerts initial chemical damage to pulmonary airway epithelia, which triggers an inflammatory response, followed by pulmonary edema and disruption of the alveolar capillary membrane $[21,22,31]$. We demonstrated that $\mathrm{HCl}$ aspiration caused severe lung injury in mice, together with significantly increased levels of NETs in BALF of mice, which were correlated with the severity of ALI/ARDS.

Large quantities of NETs in the extracellular milieu have pathological importance. NETs and their components were shown to have direct cytotoxicity in endothelial and epithelial cells [19]. Additionally, NETs can serve as a DAMPs to promote inflammation by mediating downstream inflammatory responses that lead
A

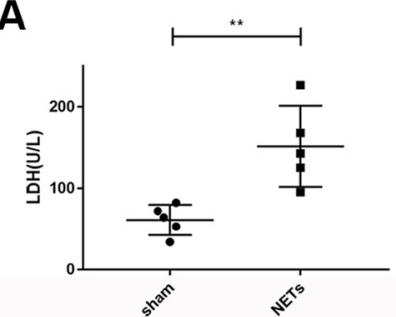

D
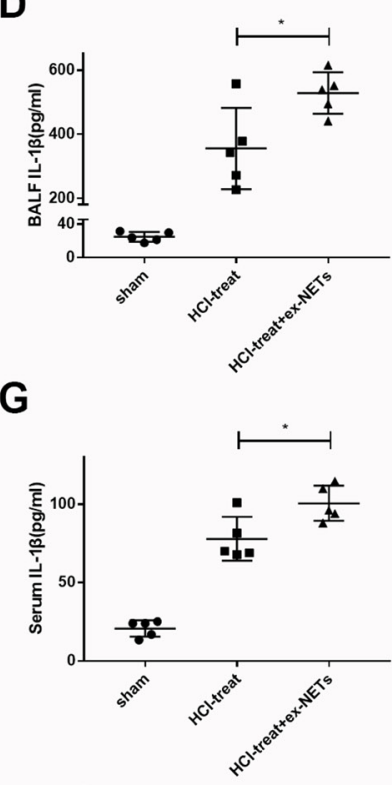

B

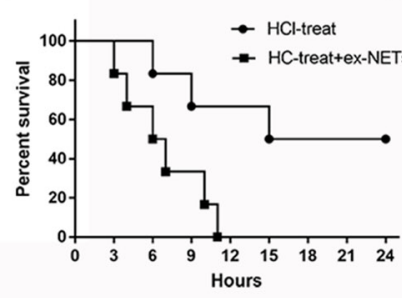

$E$

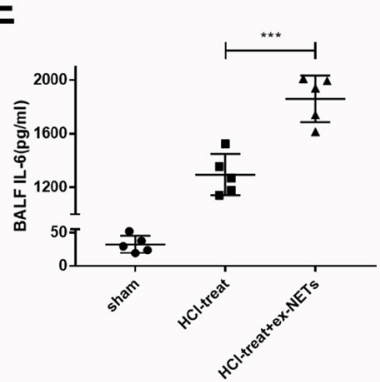

$\mathrm{H}$

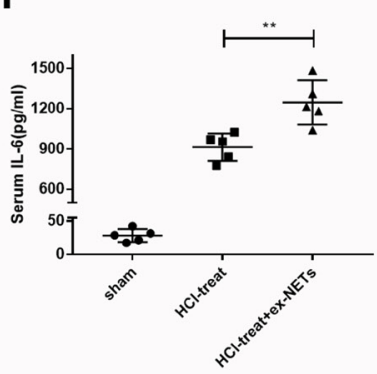

I
C
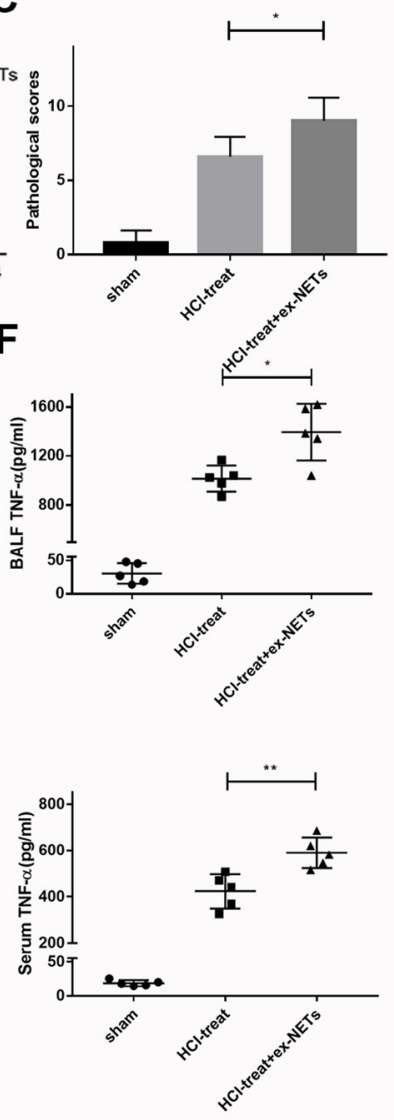

J

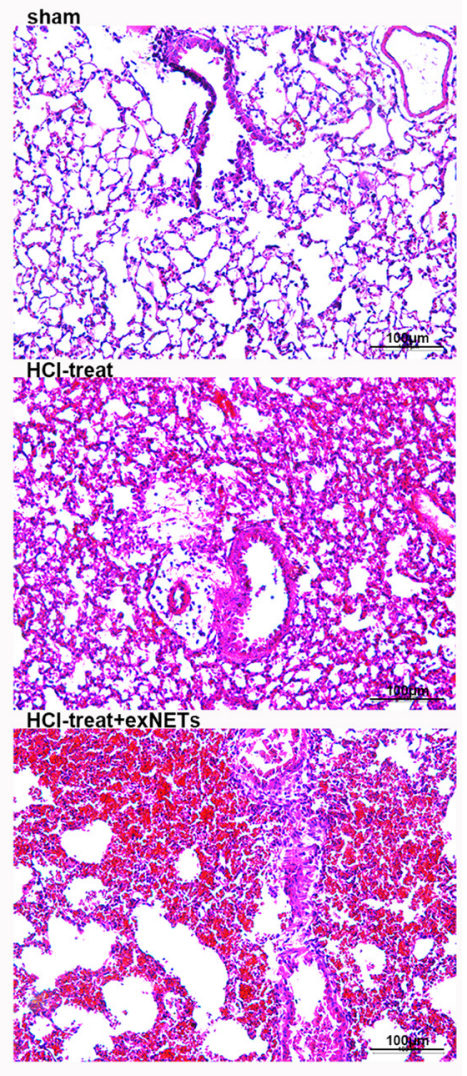

Figure 3: Exogenous NETs aggravated lung damage and inflammation in mice with ARDS. (A) Pulmonary instillation of exogenous NETs $(1.5 \mathrm{mg} / \mathrm{kg})$ caused mild lung damage in mice, as evidenced by elevated BALF LDH levels at $12 \mathrm{~h}$, compared to shamtreated mice. (B) NETs plus $\mathrm{HCl}$ significantly decreased the survival rate of HCl-treated mice. (C) Lung histological scores were higher in the NETs plus $\mathrm{HCl}$ groups than in the $\mathrm{HCl}$ group. BALF (D) IL-1 $\beta$, (E) IL-6 (F) and TNF- $\alpha$ levels were all notably increased in the NETs plus $\mathrm{HCl}$ groups compared with HCl-treated mice, as were the serum (G) IL-1 $\beta$, (H) IL-6 (I) and TNF- $\alpha$ levels. (J) Hematoxylin and eosin-stained sections of lung damage in the saline-treated group and NETs plus HCl groups compared to the $\mathrm{HCl}$ alone group. Scale bars: $100 \mu \mathrm{m} .\left({ }^{*} p<0.05,{ }^{* *} p<0.01,{ }^{* * *} p<0.001\right)$. 


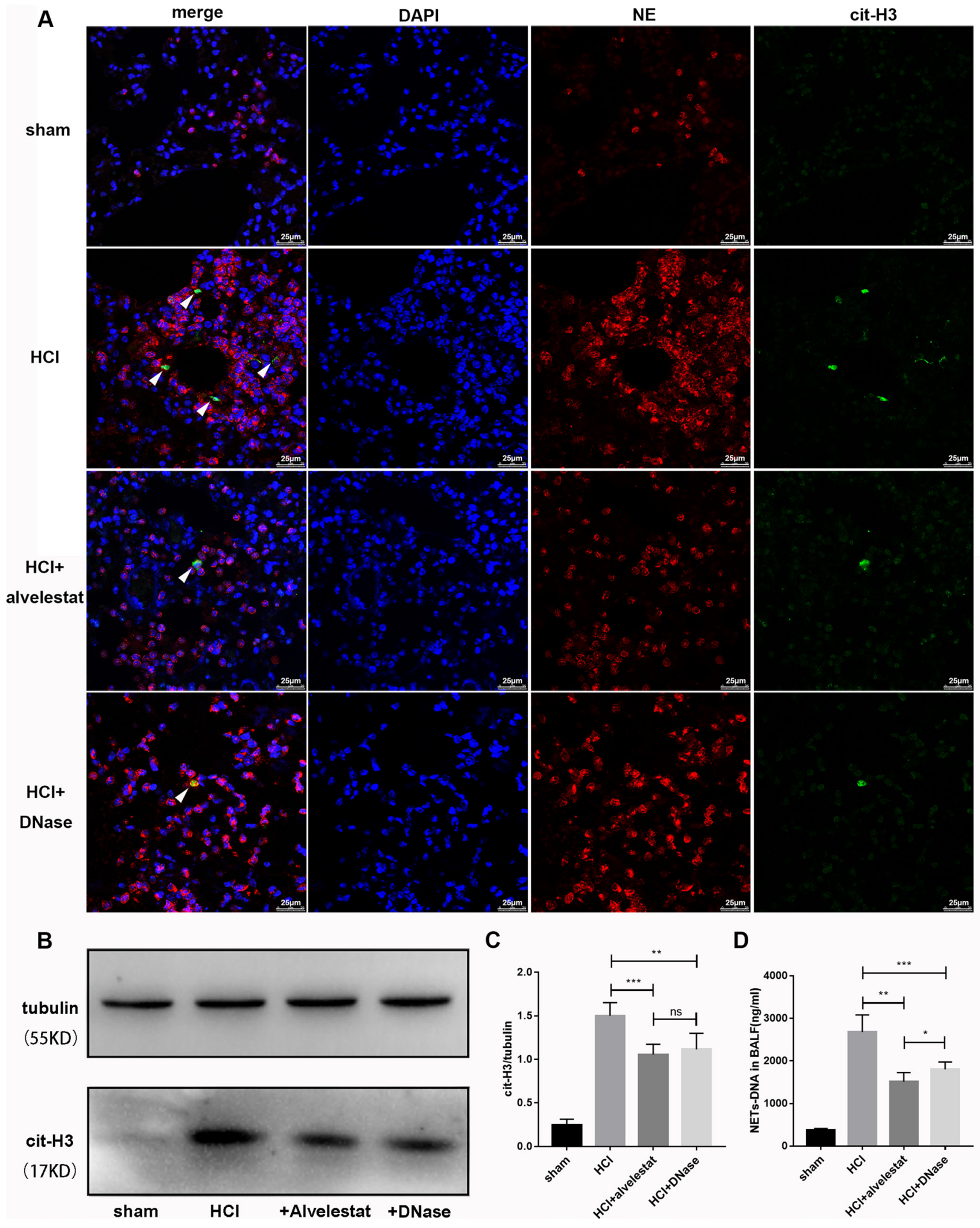

Figure 4: Alvelestat or DNase attenuated NET formation in aspiration-induced ARDS model. (A) NETs were located by confocal microscopy of lung section with immunofluorescence in the sham group, $\mathrm{HCl}$ group, $\mathrm{HCl}$ plus alvelestat group and $\mathrm{HCl}$ plus DNase group at $12 \mathrm{~h}$. Visualization of the complex of cit-H3 and NE (NETs, white arrow) was reduced in mice after administration of alvelestat and DNase. Scale bars: $50 \mu \mathrm{m}$. (B) An example of cit-H3 and tubulin detected by Western blot in the lung tissues of each group, and the cit-H3/tubulin ratio $(\mathbf{C})$ decreased in mice with administration of alvelestat and DNase, with parallel results of NET-DNA in BALF(D). $\left({ }^{*} p<0.05,{ }^{* *} p<0.01,{ }^{* * *} p<0.001\right)$. 
A

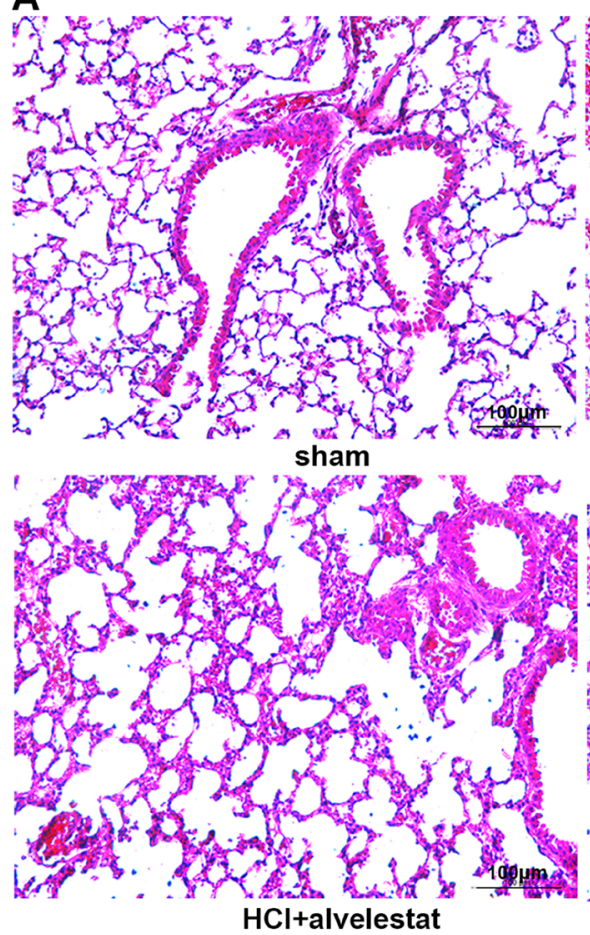

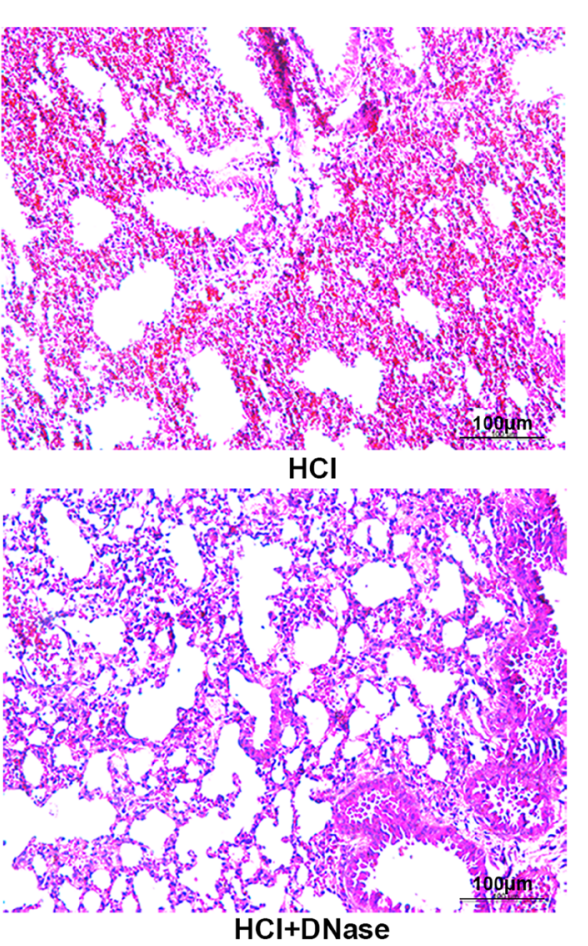
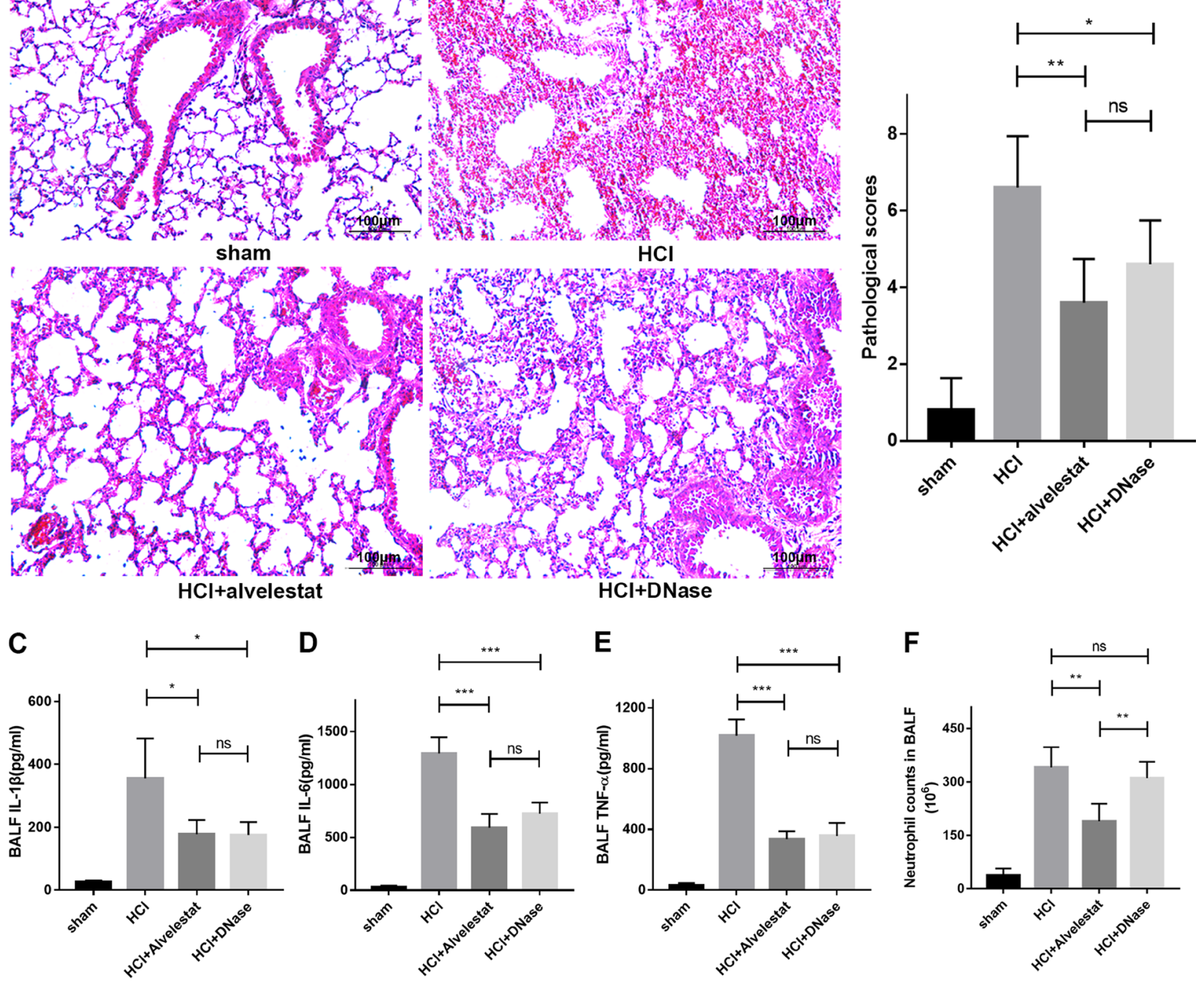

G

H
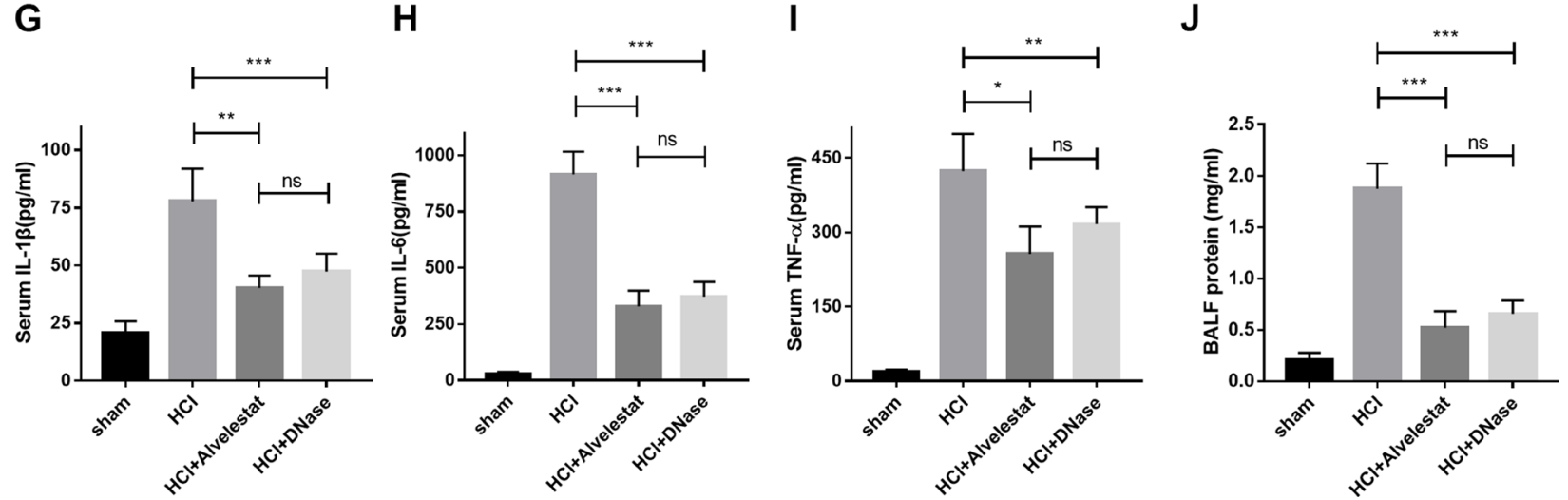

Figure 5: Alvelestat or DNase provided similar protection against ARDS. (A) Administration of alvelestat or DNase significantly alleviated lung damage in $\mathrm{HCl}$-treated mice. A representative image of $\mathrm{H} \& \mathrm{E}$-stained sections indicates substantial improvement in the lungs of alvelestat or DNase-treated mice at $12 \mathrm{~h}$. (B) Lung histological scores were lower in the alvelestat or DNase plus $\mathrm{HCl}$ groups than in the $\mathrm{HCl}$ group. BALF (C) IL-1 $\beta$, (D) IL-6 and (E) TNF- $\alpha$ were notably decreased in the alvelestat or DNase-treated groups compared with the $\mathrm{HCl}$-treated group. (F) There was no difference in neutrophil counts in BALF between the DNase plus $\mathrm{HCl}$ groups and the $\mathrm{HCl}$ only group, but neutrophil counts in BALF of alvelestat-treat mice were alleviated. Serum (G) IL-1 $\beta$, (H) IL-6 and (I) TNF- $\alpha$ (F) were also notably decreased in the alvelestat or DNase-treated groups compared with the HCl-treated group. (J) Administration of alvelestat or DNase also reduced total protein in BALF of HCl-treated mice $\left({ }^{*} p<0.05,{ }^{* *} p<0.01,{ }^{* * *} p<0.001\right)$. 
to cytokine production $[32,33]$. Consistent with these studies, we found that exogenous NETs aggravated $\mathrm{HCl}-$ induced ALI in mice, whereas blockade of NETs provided significant protection against ALI/ARDS. These findings thus confirmed the significant pathological and targetable role of NETs in acid-induced ALI/ARDS. Based on our results, we propose a possible role of NETs in mediating inflammation and lung injury after acid challenge. In

A
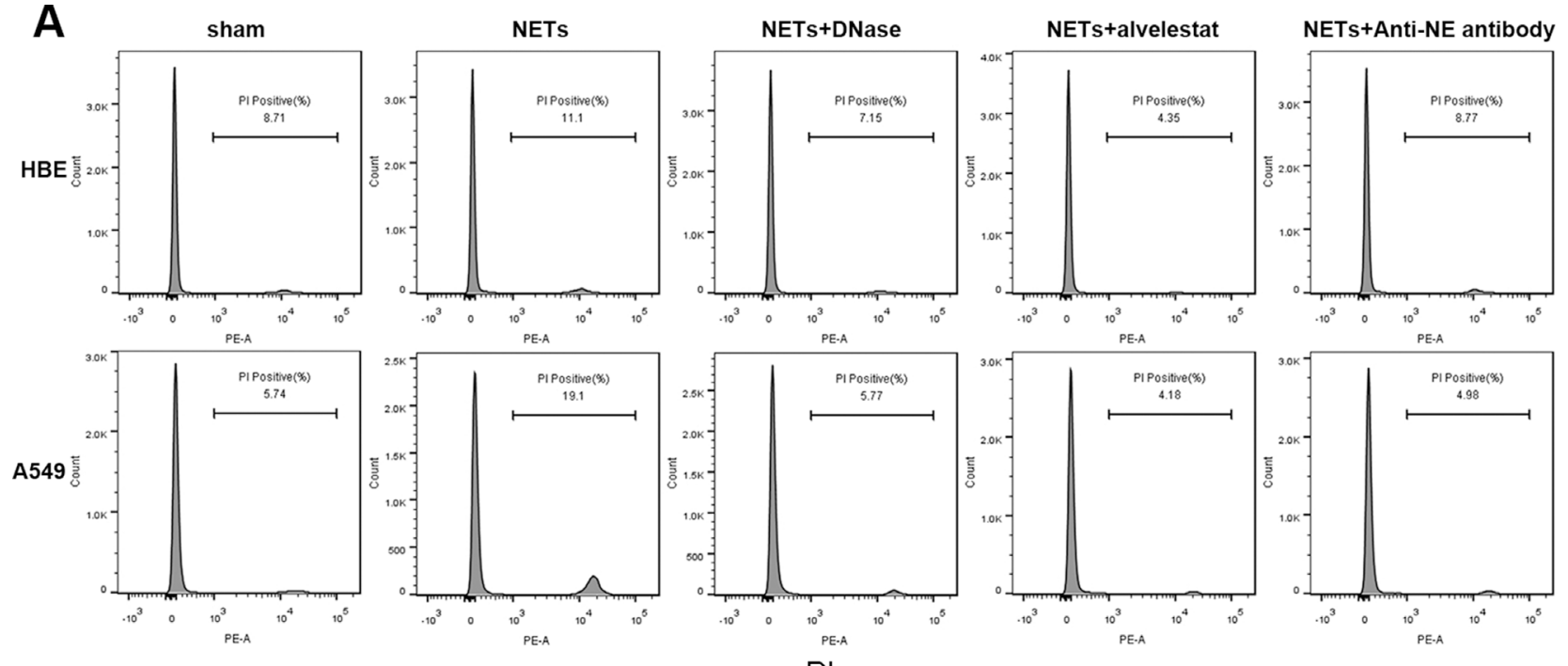

B

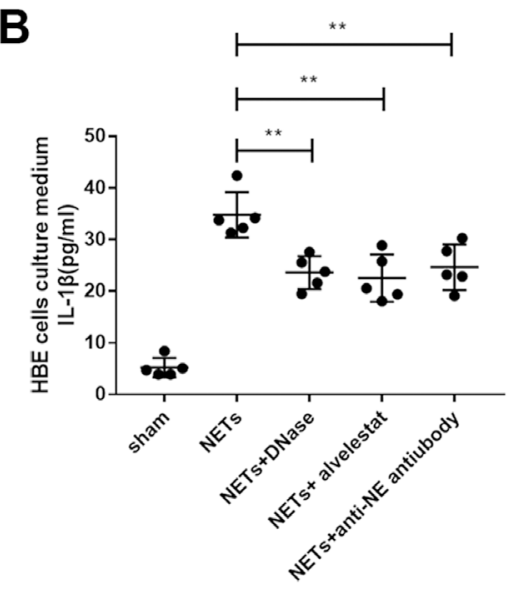

E

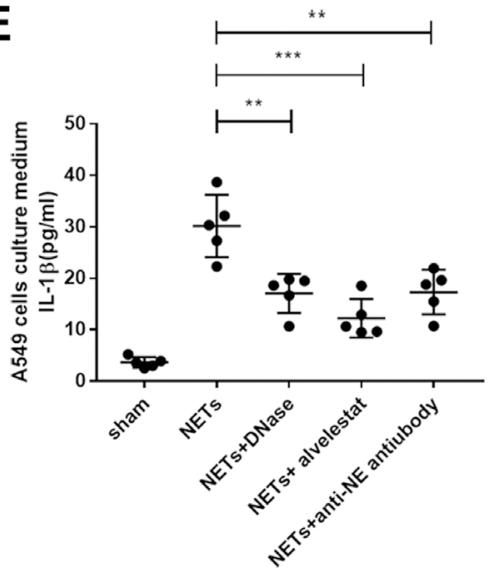

C

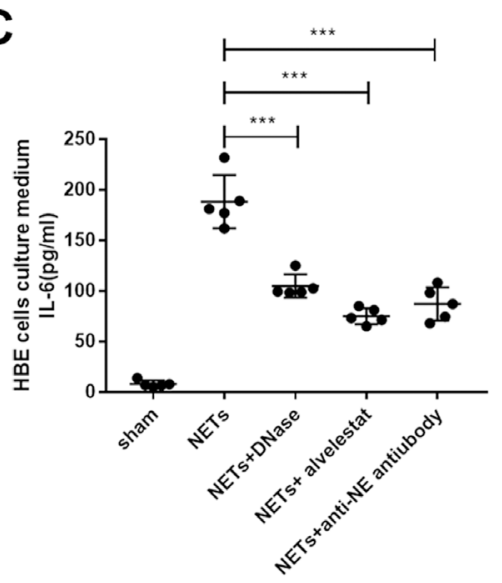

F

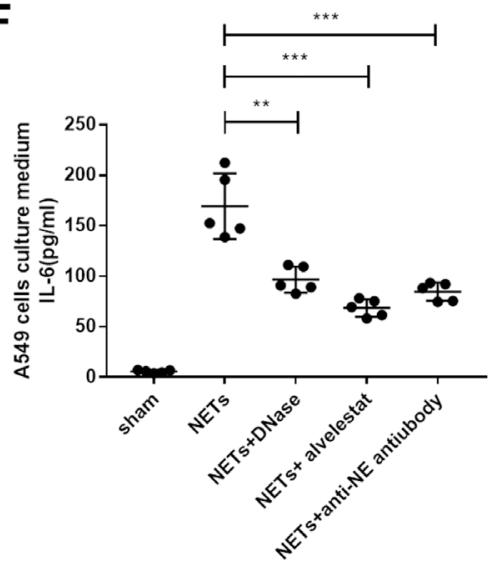

D

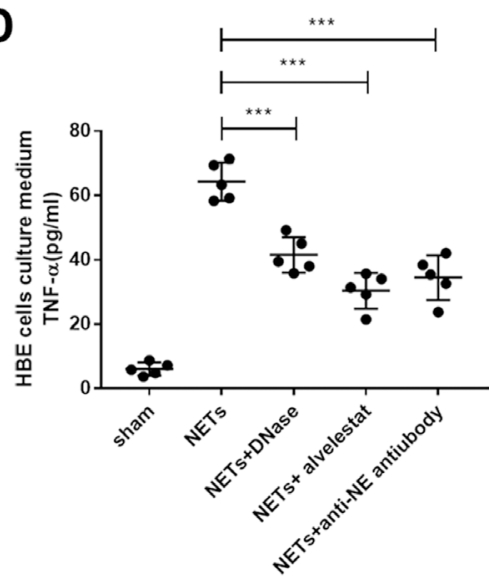

G

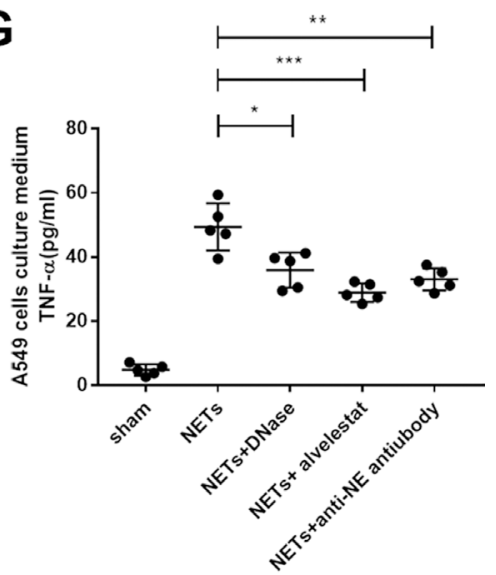

Figure 6: Alvelestat and DNase inhibited NET-mediated cell death in vitro. (A) PIstaining of cell death via flow cytometry indicated that preincubation of exogenous NETs with anti-NE antibody or alvelestat and DNase could significantly decrease A549 cell death in vitro. Administration of exogenous NETs in HBE cells (B-D) and A549 cells (E-G) increased the levels of IL-1 $\beta$, IL-6, and TNF- $\alpha$ in the supernatant of culture medium, whereas anti-NE antibody, alvelestat or DNase preincubation substantially decreased these cytokines $\left({ }^{*} p<0.05,{ }^{* *} p<0.01,{ }^{* * *} p<0.001\right)$. 
brief, neutrophil infiltration in response to $\mathrm{HCl}$ challenge releases large quantities of NETs, which are directly cytotoxic or act as endogenous DAMPs to promote innate immunity and systemic inflammation. Furthermore, NETs may, in turn, attract more inflammatory cells to damaged sites and amplify inflammation by increasing cytokine production, further contributing to ALI/ARDS. Animal studies suggest that NET attenuation (such as NE inhibitors) could be a potential therapeutic strategy. Furthermore, as an oral drug, alvelestat might provide a novel pharmacological approach to treat ALI/ARDS by targeting NETs in humans.

Notably, DNase has a protective effect as a NET degradation agent in vivo and in vitro [9, 34-36]. NE plays a central role in NET generation [17], and NE is also a component of NETs. Alvelestat, an NE inhibitor, can alleviate inflammatory responses [20, 37]. In this study, we reported that alvelestat-treated and DNase-treated mice with ALI had improved survival rates and reduced lung inflammation compared to control mice. In vitro, A549 cells were vulnerable to NETs, while HBE cells survived with NETs, suggesting that NETs may affect different mechanisms in cell death. However, inhibition of NE with antibody and inhibition of NE activity with alvelestat or degradation of NETs with DNase all significantly alleviated the A549 cell mortality rate. Furthermore, the culture media supernatant levels of IL- $1 \beta$, IL- 6 , and TNF- $\alpha$ were reduced in NE antibody-treated, alvelestat-treated and DNase-treated cells.

We thus hypothesize that inhibition of NE activity not only decreases NETs in vivo but also reduces the cytotoxicity or the inflammatory response of NETs to airway epithelial cells. Our findings suggest that drugs targeting NETs may be a therapeutic option in patients with ARDS.

In summary, our data showed that NETs play an inflammatory role in acid aspiration-induced ALI/ARDS by stimulating systemic inflammation and contributing to lung damage. The levels of NETs may act as a novel marker indicating disease activity in mice and humans with ALI/ARDS. Blockade of NETs by a specific inhibitor or NET degradation agents protected against ALI in mice. As expected, NETs and their components, such as NE, directly possess cytotoxic effects and induce an inflammatory response. A better understanding of the mechanisms underlying NET release induced by $\mathrm{HCl}$ and the effects of NETs on host immune system modulation will support the development of potential new therapeutic strategies for ALI/ARDS.

\section{MATERIALS AND METHODS}

\section{Collection and preparation of patient bronchial aspirates}

A total of 13 patients with ARDS caused by aspiration of gastric contents admitted to the intensive care units (ICU) of the Internal Nerve Medicine or Respiratory
Internal Medicine departments of the Xiangya Hospital, Central South University, Changsha, People's Republic of China were enrolled in this study. All subjects met the criteria for ARDS defined by the Berlin definition: (1) acute onset of dyspnea with history of aspiration within one week and received incubation for mechanic ventilation support, (2) $\mathrm{PaO}_{2} / \mathrm{FiO}_{2}$ equal to or less than $300 \mathrm{mmHg}$ over $48 \mathrm{~h}$, and (3) new infiltration shadow observed on chest radiography [38]. Patients who had sepsis or ARDS for more than three days were not included. A disposable suction catheter with mucus trap (Yueyue, China) was passed through the endotracheal tube to immediately collect samples of bronchial aspirate when patients were diagnosed with ARDS. Bronchial aspirate clearance is a routine practice operation in ventilation patients, and this study was approved by the Ethics Committee of Xiangya Hospital. Collected aspirates were homogenized with $0.1 \%$ dithiothreitol (DTT), filtered, and centrifuged with $500 \mathrm{~g}$ at $4^{\circ} \mathrm{C}$. Cell-free supernatant was stored at $-80^{\circ} \mathrm{C}$ for NET-DNA qualification for assessment of NET levels. Aspirate smears were prepared for qualitative analysis of NETs with immunofluorescence microscopy.

\section{Animals and acid-aspiration-induced acute lung injury model}

Six- to eight-week-old male C57BL/6 mice, weighing 18-25 g, were purchased from the Department of Experimental Animals, Central South University (Changsha, China). Mice were housed in a constant temperature at $25^{\circ} \mathrm{C}$ with a $12 \mathrm{~h}$ dark-light cycle and allowed to acclimate to the environment for three days before experimentation. All experimental protocols of this study were approved by the Institutional Animal Care and Use Committee of Health Sciences Center, Central South University, Changsha, People's Republic of China.

For the induction of acid-induced lung injury, mice were anesthetized with sodium pentobarbital $(50 \mathrm{mg} / \mathrm{kg})$ and challenged by intratracheal instillation of hydrochloric acid $(\mathrm{HCl}, 0.1 \mathrm{~N}, 1.5 \mu \mathrm{l} / \mathrm{g})$ into the lung. The mice in the control group underwent a similar procedure but received sterile saline instead.

\section{Evaluation of ARDS in mice}

The severity of ARDS was evaluated by blood gas analysis, pulmonary edema, alveolar epithelial permeability and lung histology. Left ventricle paracentesis was processed with $1 \mathrm{ml}$ syringes to obtain arterial blood. We analyzed arterial partial oxygen tension $\left(\mathrm{PaO}_{2}\right)$ of arterial blood with a gas analyzer at different time points after hydrochloric acid aspiration. The wet to dry lung weight ratio was calculated to assess pulmonary edema. Lung tissues were rapidly cut and flushed in phosphate-buffered saline (PBS) to remove the remaining blood. After excessive PBS was carefully removed by 
tissue paper, the lung tissues were weighed as wet weight. Then, the tissues were parched in an oven at $60^{\circ} \mathrm{C}$ for $72 \mathrm{~h}$, followed by a second weighing as dry weight.

Protein levels and the number of neutrophils in BALF were measured to evaluate alveolar epithelial permeability. We used $1 \mathrm{ml}$ PBS for lavage of mouse lungs three times to obtain BALF. BALF was centrifuged at $500 \times \mathrm{g}$ for $10 \mathrm{~min}$ at $4^{\circ} \mathrm{C}$. Cell-free supernatant protein concentration was measured by a bicinchoninic acid protein assay (Biomiga, USA), while the pellets were resuspended for a cell suspension for neutrophil count by performing Wright's staining on a glass slide.

For lung histology, part of the lung tissues was fixed with $4 \%$ paraformaldehyde and embedded in paraffin, and $5 \mu \mathrm{m}$ sections were acquired and stained with hematoxylin and eosin. The stained sections were evaluated and scored in random visual fields. The severity of lung injury was assessed with a semi-quantitative analysis by scoring from 0 (no lesion) to 4 (significant and extended lesions) according to the following parameters: vascular congestion, alveolar necrosis, neutrophil infiltration and macrophage infiltration

\section{Preparation of mouse samples}

In another group of mice, $1 \mathrm{ml}$ PBS was used in the lung to obtain BALF. Centrifuged cell-free supernatants were stored at $-80^{\circ} \mathrm{C}$ until further analysis. The lung lobes were rapidly excised, flash frozen in liquid nitrogen, and stored at $-80^{\circ} \mathrm{C}$. Mouse blood was collected by retro-orbital bleeding into a tube containing EDTA as an anticoagulant and centrifuged to separate plasma, and the plasma was stored at $-80^{\circ} \mathrm{C}$.

\section{Generation, isolation and purification of NETs}

Mouse neutrophils were isolated from bone marrow and purified by density gradient centrifugation as previous described [39]. Briefly, the muscles and joints from the femur and tibia, which were collected from euthanized mice, were removed without breaking the bones. Then, epiphyses of the bones were cut, and bone marrow was flushed with a $1 \mathrm{ml}$ syringe at both ends of the bone. Next, cells were suspended in a volume of $3 \mathrm{ml}$, followed by red blood cell lysis. Then, $3 \mathrm{ml}$ of Histopaque 1119 was added in a $15 \mathrm{ml}$ tube at the bottom with $3 \mathrm{ml}$ of Histopaque 1083 overlaid, and the bone marrow cell suspension was added on the top. The layered solution was centrifuged without a brake, and the neutrophils at the interface of the Histopaque 1119 and Histopaque 1083 layers were collected with neutrophils typically $>95 \%$ viable and $>90 \%$ pure.

Human neutrophils were isolated from peripheral blood donated by healthy volunteers as previously described [40]. Briefly, blood was overlaid on lymphocyte separation solution (LSM), and the layered solution was centrifuged at $800 \mathrm{~g}$ for $30 \mathrm{~min}$ at $21^{\circ} \mathrm{C}$ without a break.
The bottom red layer was retained and resuspended with 3\% Dextran-PBS solution; then, the solution was incubated for $30 \mathrm{~min}$. Next, the supernatant was transferred into fresh tubes for centrifugation for red blood cell lysis and neutrophil enrichment, with neutrophils typically $>95 \%$ viable and $>95 \%$ pure.

Both mouse and human-derived neutrophils were stimulated with $500 \mathrm{nM}$ of PMA for four h at $37^{\circ} \mathrm{C}$ and $5 \%$ $\mathrm{CO}_{2}$ to allow NETosis. The media were gently aspirated and discarded, while the bottom of the dishes was washed with cold PBS to remove all adherent material. The solution was centrifuged for $5 \mathrm{~min}$ at $450 \mathrm{~g}$ at $4^{\circ} \mathrm{C}$ to remain cell-free NET-rich supernatant. The supernatant continued to spin for $10 \mathrm{~min}$ at $18,000 \mathrm{~g}$ at $4^{\circ} \mathrm{C}$ to allow the DNA to pellet. The pellets were all obtained in PBS at a concentration corresponding to $2 \times 10^{7}$ neutrophils per $100 \mu \mathrm{l}$. The cell-free NET stock yielded a DNA concentration range between $140-180 \mathrm{ng} / \mu \mathrm{l}$ measured by a DNA quantification tool.

\section{Treatment with exogenous NETs, alvelestat and DNase}

In a separate set of experiments, we examined whether NETs released after acid-caused lung injury contributed to the pathogenesis of ARDS. To this end, mouse-derived NETs with a DNA concentration of $1.5 \mathrm{mg}$ / $\mathrm{kg}$ were administered to mice by intratracheal injection shortly after the $\mathrm{HCl}$ challenge. Meanwhile, another group of mice received a $(5 \mathrm{mg} / \mathrm{kg})$ by subcutaneous injection immediately after acid aspiration, and some received DNase I (5 mg/kg) as a positive control, with the aim of further confirming the pathogenic role of NETs as well as exploring possible treatment strategies. The dosages of NETs, alvelestat and DNase were based on previous experiments $[9,20,41]$.

\section{Qualitative and quantitative analysis of NETs}

NETs detected in sputum of patients' bronchial aspirates and mouse lung tissues we identified by colocalization of cit-H3 and NE by immunofluorescence staining. Briefly, sputum smears were prepared and fixed in PLP fixative (3\% paraformaldehyde, L-lysine monohydrate, sodium m-periodate, $0.1 \mathrm{M}$ disodium hydrogen orthophosphate), dried and coated in $15 \%$ sucrose. For cit-H3 and NE detection, slides were blocked with PBS containing 2\% BSA and 3\% donkey serum and then incubated for $2 \mathrm{~h}$ at room temperature (RT) with rabbit anti-cit $\mathrm{H} 3$ antibody (Abcam) and goat anti-NE antibody (Santa Cruz) as primary antibodies. Paraffinembedded mouse lungs were sectioned $(5 \mu \mathrm{m})$ and mounted on glass slides. After dewaxing, permeabilizing and blocking, the sections were incubated with rabbit anti-cit-H3 antibody (Abcam) and goat anti-NE antibody (Santa Cruz, sc-9520) overnight at $4^{\circ} \mathrm{C}$.All samples were detected with Alexa Fluor 488 donkey anti-rabbit 
(Abcam) and Alexa Fluor 647 donkey anti-goat (1:500; Abcam) secondary antibodies for $1 \mathrm{~h}$ at RT and mounted using ProLong Gold Antifade Mountant with DAPI (Life Technologies, Carlsbad, CA, USA) to detect DNA.

For determination of NET levels in cell-free bronchial aspiration supernatants of patients and the mouse BALF, extracellular DNA was quantitated using the Quant-iT PicoGreen dsDNA Assay Kit (P7589, Invitrogen, Carlsbad, CA) followed the manufacturer's instructions. This assay selectively detects double-stranded DNA, which we quantitated in $10 \mu \mathrm{L}$ of bronchial aspiration supernatant and mouse BALF against a DNA standard curve of $0-2000 \mathrm{ng} / \mu \mathrm{L}$.

Western blot assays were also performed using BALF and whole cell lysates obtained from mouse lung tissues as a semi-quantitative analysis of NETs for cit-H3, which can be a specific predictor of NETs. Membranes were incubated overnight with the anti-Cit-H3 (1:1000, Abcam) antibody and an anti-GAPDH antibody (1:2000, Proteintech) as an internal control.

\section{Quantification of inflammatory indicators}

IL-1 $\beta$, IL- 6 and TNF- $\alpha$ levels in patients' bronchial aspiration supernatant and mouse plasma and BALF were determined using commercially available human and mouse IL-1 $\beta$, IL-6 and TNF- $\alpha$ enzyme-linked immunosorbent assay (ELISA) kits (eBioscience, USA) according to the manufacturer's instructions.

\section{Assay for NET cytotoxicity in vitro}

Human bronchial epithelial cells (HBE) and human alveolar epithelial cells (A549) were obtained from the American Type Culture Collection. Cells were cultured in Dulbecco's modified Eagle's medium (DMEM) supplemented with $10 \%$ fetal bovine serum and $1 \%$ penicillin-streptomycin. After the cells had grown to $70-80 \%$ confluence, they were stimulated with humanderived NETs (DNA concentration at $5 \mu \mathrm{g} / \mathrm{ml}$ ) for 16 $\mathrm{h}$ at $37^{\circ} \mathrm{C}$. In another set of experiment, cells added to NETs were cocultured with anti-NE antibody $(20 \mu \mathrm{g} / \mathrm{ml})$ or alvelestat $(20 \mu \mathrm{g} / \mathrm{ml})$. Cells were collected and stained with propidium iodide to analyze cell damage via flow cytometry. Additionally, cell culture supernatants were analyzed for IL-1 $\beta$, IL-6, and TNF- $\alpha$ levels with ELISA kits from eBioscience (eBioscience, USA), according to the manufacturer's protocol.

\section{Statistical analysis}

Results are expressed as the mean \pm standard deviation(SD). Differences among more than two sets of data were assessed by performing one-way ANOVA followed by Tukey's multiple comparisons test. A value of $P<0.05$ (two-tailed) was considered statistically significant.

\section{CONFLICTS OF INTEREST}

None.

\section{FUNDING}

The study was supported by the National Natural Science Foundation of China (Grant No. 81470266, 81770080) and the Independent Explore Innovative Projects of Central South University (Grant No. 2017zzts208).

\section{REFERENCES}

1. Matthay MA, Zemans RL. The acute respiratory distress syndrome: pathogenesis and treatment. Annu Rev Pathol. 2011; 6:147-63. https://doi.org/10.1146/annurevpathol-011110-130158.

2. Matthay MA, Zimmerman GA. Acute lung injury and the acute respiratory distress syndrome: four decades of inquiry into pathogenesis and rational management. Am J Respir Cell Mol Biol. 2005; 33:319-27. https://doi.org/10.1165/ rcmb.F305.

3. Raghavendran K, Nemzek J, Napolitano LM, Knight PR. Aspiration-induced lung injury. Crit Care Med. 2011; 39:818-26. https://doi.org/10.1097/ CCM.0b013e31820a856b.

4. Matt U, Warszawska JM, Bauer M, Dietl W, Mesteri I, Doninger B, Haslinger I, Schabbauer G, Perkmann T, Binder CJ, Reingruber S, Petzelbauer P, Knapp S. Bbeta(15-42) protects against acid-induced acute lung injury and secondary pseudomonas pneumonia in vivo. Am J Respir Crit Care Med. 2009; 180:1208-17. https://doi. org/10.1164/rccm.200904-0626OC.

5. Brinkmann V, Reichard U, Goosmann C, Fauler B, Uhlemann Y, Weiss DS, Weinrauch Y, Zychlinsky A. Neutrophil extracellular traps kill bacteria. Science. 2004; 303:1532-5. https://doi.org/10.1126/science.1092385.

6. Camicia G, Pozner R, de Larrañaga G. Neutrophil Extracellular Traps in Sepsis. Shock. 2014; 42:286-94. https://doi.org/10.1097/shk.0000000000000221.

7. Huang H, Tohme S, Al-Khafaji AB, Tai S, Loughran P, Chen L, Wang S, Kim J, Billiar T, Wang Y, Tsung A. Damage-associated molecular pattern-activated neutrophil extracellular trap exacerbates sterile inflammatory liver injury. Hepatology. 2015; 62:600-14. https://doi. org/10.1002/hep.27841.

8. Caudrillier A, Kessenbrock K, Gilliss BM, Nguyen JX, Marques MB, Monestier M, Toy P, Werb Z, Looney MR. Platelets induce neutrophil extracellular traps in transfusionrelated acute lung injury. J Clin Invest. 2012; 122:2661-71. https://doi.org/10.1172/jci61303.

9. Liu S, Su X, Pan P, Zhang L, Hu Y, Tan H, Wu D, Liu B, Li H, Li H, Li Y, Dai M, Li Y, et al. Neutrophil extracellular 
traps are indirectly triggered by lipopolysaccharide and contribute to acute lung injury. Sci Rep. 2016; 6:37252. https://doi.org/10.1038/srep37252.

10. Prather AD, Smith TR, Poletto DM, Tavora F, Chung JH, Nallamshetty L, Hazelton TR, Rojas CA. Aspiration-related lung diseases. J Thorac Imaging. 2014; 29:304-9. https:// doi.org/10.1097/rti.0000000000000092.

11. Bakowitz M, Bruns B, McCunn M. Acute lung injury and the acute respiratory distress syndrome in the injured patient. Scand J Trauma Resusc Emerg Med. 2012; 20:54. https://doi.org/10.1186/1757-7241-20-54.

12. Fanelli V, Vlachou A, Ghannadian S, Simonetti U, Slutsky AS, Zhang H. Acute respiratory distress syndrome: new definition, current and future therapeutic options. J Thorac Dis. 2013; 5:326-34. https://doi.org/10.3978/j.issn.20721439.2013.04.05.

13. Rubenfeld GD, Caldwell E, Peabody E, Weaver J, Martin DP, Neff M, Stern EJ, Hudson LD. Incidence and outcomes of acute lung injury. N Engl J Med. 2005; 353:1685-93. https://doi.org/10.1056/NEJMoa050333.

14. Folkesson HG, Matthay MA, Hebert CA, Broaddus VC. Acid aspiration-induced lung injury in rabbits is mediated by interleukin-8-dependent mechanisms. J Clin Invest. 1995; 96:107-16. https://doi.org/10.1172/jci118009.

15. Paris AJ, Liu Y, Mei J, Dai N, Guo L, Spruce LA, Hudock KM, Brenner JS, Zacharias WJ, Mei HD, Slamowitz AR, Bhamidipati K, Beers MF, et al. Neutrophils promote alveolar epithelial regeneration by enhancing type II pneumocyte proliferation in a model of acid-induced acute lung injury. Am J Physiol Lung Cell Mol Physiol. 2016; 311:L1062-175. https://doi.org/10.1152/ajplung.00327.2016.

16. Kardara M, Hatziantoniou S, Sfika A, Vassiliou AG, Mourelatou E, Muagkou C, Armaganidis A, Roussos C, Orfanos SE, Kotanidou A, Maniatis NA. Caveolar uptake and endothelial-protective effects of nanostructured lipid carriers in acid aspiration murine acute lung injury. Pharm Res. 2013; 30:1836-47. https://doi.org/10.1007/s11095013-1027-2.

17. Papayannopoulos V, Metzler KD, Hakkim A, Zychlinsky A. Neutrophil elastase and myeloperoxidase regulate the formation of neutrophil extracellular traps. J Cell Biol. 2010; 191:677-91. https://doi.org/10.1083/jcb.201006052.

18. Urban CF, Ermert D, Schmid M, Abu-Abed U, Goosmann C, Nacken W, Brinkmann V, Jungblut PR, Zychlinsky A. Neutrophil extracellular traps contain calprotectin, a cytosolic protein complex involved in host defense against Candida albicans. PLoS Pathog. 2009; 5:e1000639. https:// doi.org/10.1371/journal.ppat.1000639.

19. Saffarzadeh M, Juenemann C, Queisser MA, Lochnit G, Barreto G, Galuska SP, Lohmeyer J, Preissner KT. Neutrophil extracellular traps directly induce epithelial and endothelial cell death: a predominant role of histones. PLoS One. 2012; 7:e32366. https://doi.org/10.1371/journal. pone. 0032366 .
20. Stevens T, Ekholm K, Granse M, Lindahl M, Kozma V, Jungar C, Ottosson T, Falk-Hakansson H, Churg A, Wright JL, Lal H, Sanfridson A. AZD9668: pharmacological characterization of a novel oral inhibitor of neutrophil elastase. J Pharmacol Exp Ther. 2011; 339:313-20. https:// doi.org/10.1124/jpet.111.182139.

21. Cornelio Favarin D, Martins Teixeira M, Lemos de Andrade E, de Freitas Alves C, Lazo Chica JE, Arterio Sorgi C, Faccioli LH, Paula Rogerio A. Anti-inflammatory effects of ellagic acid on acute lung injury induced by acid in mice. Mediators Inflamm. 2013; 2013:164202. https://doi. org/10.1155/2013/164202.

22. Davidson BA, Vethanayagam RR, Grimm MJ, Mullan BA, Raghavendran K, Blackwell TS, Freeman ML, Ayyasamy V, Singh KK, Sporn MB, Itagaki K, Hauser CJ, Knight $\mathrm{PR}$, et al. NADPH oxidase and Nrf2 regulate gastric aspiration-induced inflammation and acute lung injury. J Immunol. 2013; 190:1714-24. https://doi.org/10.4049/ jimmunol.1202410.

23. Bosmann M, Grailer JJ, Ruemmler R, Russkamp NF, Zetoune FS, Sarma JV, Standiford TJ, Ward PA. Extracellular histones are essential effectors of C5aRand C5L2-mediated tissue damage and inflammation in acute lung injury. Faseb j. 2013; 27:5010-21. https://doi. org/10.1096/fj.13-236380.

24. Lockey DJ, Coats T, Parr MJ. Aspiration in severe trauma: a prospective study. Anaesthesia. 1999; 54:1097-8.

25. Chen GY, Nunez G. Sterile inflammation: sensing and reacting to damage. Nat Rev Immunol. 2010; 10:826-37. https://doi.org/10.1038/nri2873.

26. De Meyer SF, Suidan GL, Fuchs TA, Monestier M, Wagner DD. Extracellular chromatin is an important mediator of ischemic stroke in mice. Arterioscler Thromb Vasc Biol. 2012; 32:1884-91. https://doi.org/10.1161/ atvbaha.112.250993.

27. Henson PM. Dampening inflammation. Nat Immunol. 2005; 6:1179-81. https://doi.org/10.1038/ni1205-1179.

28. Wu D, Pan P, Su X, Zhang L, Qin Q, Tan H, Huang L, Li Y. Interferon Regulatory Factor-1 Mediates Alveolar Macrophage Pyroptosis During LPS-Induced Acute Lung Injury in Mice. Shock. 2016; 46:329-38. https://doi. org/10.1097/shk.0000000000000595.

29. Muller-Redetzky H. Targeting neutrophil extracellular traps in acute lung injury: a novel therapeutic approach in acute respiratory distress syndrome? Anesthesiology. 2015; 122:725-7. https://doi.org/10.1097/aln.0000000000000604.

30. Jorch SK, Kubes P. An emerging role for neutrophil extracellular traps in noninfectious disease. Nat Med. 2017; 23:279-87. https://doi.org/10.1038/nm.4294.

31. Ambrosio AM, Luo R, Fantoni DT, Gutierres C, Lu Q, Gu WJ, Otsuki DA, Malbouisson LM, Auler JO Jr, Rouby JJ. Effects of positive end-expiratory pressure titration and recruitment maneuver on lung inflammation and hyperinflation in experimental acid aspiration-induced lung 
injury. Anesthesiology. 2012; 117:1322-34. https://doi. org/10.1097/ALN.0b013e31827542aa.

32. Saitoh T, Komano J, Saitoh Y, Misawa T, Takahama M, Kozaki T, Uehata T, Iwasaki H, Omori H, Yamaoka $\mathrm{S}$, Yamamoto N, Akira S. Neutrophil extracellular traps mediate a host defense response to human immunodeficiency virus-1. Cell Host Microbe. 2012; 12:109-16. https://doi.org/10.1016/j.chom.2012.05.015.

33. Sabbione F, Keitelman IA, Iula L, Ferrero M, Giordano MN, Baldi P, Rumbo M, Jancic C, Trevani AS. Neutrophil Extracellular Traps Stimulate Proinflammatory Responses in Human Airway Epithelial Cells. J Innate Immun. 2017. https://doi.org/10.1159/000460293.

34. Ge L, Zhou X, Ji WJ, Lu RY, Zhang Y, Zhang YD, Ma YQ, Zhao JH, Li YM. Neutrophil extracellular traps in ischemia-reperfusion injury-induced myocardial no-reflow: therapeutic potential of DNase-based reperfusion strategy. Am J Physiol Heart Circ Physiol. 2015; 308:H500-9. https://doi.org/10.1152/ajpheart.00381.2014.

35. Sorensen OE, Borregaard N. Neutrophil extracellular traps the dark side of neutrophils. J Clin Invest. 2016; 126:161220. https://doi.org/10.1172/jci84538.

36. Jimenez-Alcazar M, Napirei M, Panda R, Kohler EC, Kremer Hovinga JA, Mannherz HG, Peine S, Renne T, Lammle B, Fuchs TA. Impaired DNase1-mediated degradation of neutrophil extracellular traps is associated with acute thrombotic microangiopathies. J Thromb Haemost. 2015; 13:732-42. https://doi.org/10.1111/jth.12796.
37. von Nussbaum F, Li VM. Neutrophil elastase inhibitors for the treatment of (cardio)pulmonary diseases: Into clinical testing with pre-adaptive pharmacophores. Bioorg Med Chem Lett. 2015; 25:4370-81. https://doi.org/10.1016/j. bmcl.2015.08.049.

38. Ferguson ND, Fan E, Camporota L, Antonelli M, Anzueto A, Beale R, Brochard L, Brower R, Esteban A, Gattinoni L, Rhodes A, Slutsky AS, Vincent JL, et al. The Berlin definition of ARDS: an expanded rationale, justification, and supplementary material. Intensive Care Medicine. 2012; 38:1573-82. https://doi.org/10.1007/s00134-0122682-1.

39. Swamydas M, Lionakis MS. Isolation, purification and labeling of mouse bone marrow neutrophils for functional studies and adoptive transfer experiments. J Vis Exp. 2013: e50586. https://doi.org/10.3791/50586.

40. Najmeh S, Cools-Lartigue J, Giannias B, Spicer J, Ferri LE. Simplified Human Neutrophil Extracellular Traps (NETs) Isolation and Handling. J Vis Exp. 2015. https:// doi.org/10.3791/52687.

41. Brill A, Fuchs TA, Savchenko AS, Thomas GM, Martinod K, De Meyer SF, Bhandari AA, Wagner DD. Neutrophil extracellular traps promote deep vein thrombosis in mice. $\mathrm{J}$ Thromb Haemost. 2012; 10:136-44. https://doi.org/10.1111/ j.1538-7836.2011.04544.x. 